\title{
Is Parkinson's Disease truly a disease or simply an indication of a long life
}

\author{
Roy G Beran ${ }^{1,2,3}$ \\ ${ }^{1}$ Conjoint Professor, University of New South Wales, Australia \\ ${ }^{2}$ Professor, School of Medicine, Griffith University, Queensland, Australia \\ ${ }^{3}$ Professor, Medical Law, Sechenov, Moscow First State University, Russia
}

\begin{abstract}
Parkinson described paralysis agitans more than 200 years ago but reference to the condition dates back to ancient times, thereby suggesting it is far more common than many appreciate.

While the relationship of Parkinson's Disease to the reduction of dopamine is not disputed, it is accepted that the proteins, involved in Parkinson's Disease, such as $\alpha$-synuclein, UCH-L1, PINK1 or DJ-1 are also involved in the aging process.
\end{abstract}

Accepting that there are genetic conditions that predispose to the early expression of Parkinson's Disease, the argument remains that Parkinson's Disease is not a disease entity per se but rather the expression of aging and if one lives long enough one will acquire Parkinson's Disease.

James Parkinson (11/04/1755 - 21/12/1824), after whom Parkinson's Disease was eponymously named, wrote his "Essay of the Shaking Palsy" more than 200 years ago [1], in 1817. He failed the entry criteria to study medicine and came to Australia for the Gold Rush and was a lighthouse keeper near Hobart in Tasmania [1]. He has been described as an "English apothecary surgeon, geologist, palentologist, and political activist [2]. Elements of so-called Parkinson's Disease were identifiable in ancient Chinese, Indian, Babylonian and Greek texts, thereby establishing its relatively broad-based, ubiquitous nature across cultures and societies [2].

Whereas Parkinson identified the characteristic “... resting tremor, stiffness and characteristic station and gait....that he called paralysis agitans...", in 1872 Charcot added bradykinesia as a seminal feature [2]. There remains no absolutely reliable, objective test to clinically diagnose Parkinson's Disease, with the diagnosis being dependent on expert opinion as the benchmark "gold standard" [3]. The diagnosis remains reliant on the cardinal features of bradykinesia, rigidity and resting tremor [4] with a basic requirement of at least two out of these three features. Various primitive reflexes, such as the glabellar tap, grasp reflexes and palmar mental/nasopalpebral reflexes, when present, assist in the clinical diagnosis of Parkinson's Disease [5]. On this basis alone, Parkinson's Disease is a clinical diagnosis that relies on the acumen of the clinician involved. After many years of practice, as a consultant physician/neurologist, it has become apparent that Parkinson's Disease is far more common than most observers accept. With features identified in ancient societies [2] the question arises whether Parkinson's Disease is truly a disease, thereby establishing it as a pathological entity, or whether it merely reflects a pattern of expression that is associated with the normal aging process.

It is accepted that Parkinson's Disease results from reduction of dopamine in the basal ganglia [6] with consequential losses in the thalamus and cortex [6]. This has resulted in enhanced appreciation of the link between degeneration of dopamine neurones in the midbrain and the development of Parkinsonism [6]. It is widely accepted that those proteins involved in the pathogenesis of Parkinson's Disease, such as $\alpha$-synuclein, UCH-L1, PINK1 or DJ-1 are also involved in aging [6]. "....Present data suggests that Parkinson's Disease could be the expression of aging on a cell population with high vulnerability to aging..." [6]. It is hypothesised that those neurones which degenerate during the evolution of Parkinson's Disease also degenerate during the normal aging process and that this may represent a local expression of aging on a particularly vulnerable cell population due to an increased number of synaptic terminals, mitochondria and unmyelinated axons [7]. It is acknowledged that one of the dominant determinates of clinical progression of Parkinson's Disease is advancing age, rather than disease duration, and there is a biological interaction between the disease process and aging on non-dopaminergic structures [8]. The prevalence of Parkinsonian features is significantly increased in the older population [9] with an artificial separation and differentiation between Parkinson's Disease and Parkinsonism [9].

\section{Conclusion}

Taking all of these features into account, complemented by a long experience of successful management of Parkinson's Disease, predicated on very early introduction of anti-Parkinsonian remedies, particularly L'dopa [10], has led to the supposition that Parkinson's Disease may not be a specific disease entity but rather an expression of aging that

${ }^{\star}$ Correspondence to: Roy G Beran, Suite 5, Level 6, 12 Thomas Street, CHATSWOOD NSW 2067, Australia, Tel: 6129415 3800, Fax: 6129413 1353, E-mail: roy@royberan.com

Key words: parkinson's disease, aging, pathophysiology, association

Received: June 11, 2020; Accepted: June 19, 2020; Published: June 25, 2020 
was initially recognised and documented in ancient times. Accepting one can trace references to the "disease" to the ancient records from China, India, Babylon and Greece [2] and even within the present era of scientific advancement and technological achievement, the diagnosis remains a clinical determination, [3] there exists cogent argument to justify the stance that the so-called entity "Parkinson's Disease" is merely an expression of the aging process. Perhaps it is not a disease at all but simply an indication of a long life with the advancement of medicine realising more people living to the vulnerable age bracket. This does not negate there being genetic predispositions, resulting in premature expression of the Parkinsonian constellation, as associated with UCH-L1 or PINK1. A critical evaluation of both pathophysiology and the clinical picture, over centuries, endorses the position that Parkinson's Disease is more a factor of aging than a specific pathological entity, hence the various types of Parkinsonism. The hypothesis is that if one lives long enough one will develop Parkinsonian features.

\section{References}

1. Lees A, Eyre P, Brown P (2018) The true face of James Parkinson. Lancet Neurol 17: 507. [Crossref]

2. Mulhearn RJ (1971) The history of James Parkinson and his disease. Aust N Z J Med 1: 1-6. [Crossref]
3. Postuma RB, Berg D, Adler CH, Bloem BR, Chan P, et al. (2016) The new definition and diagnostic criteria of Parkinson's Disease. Lancet Neurol 15: 546-548. [Crossref]

4. Postuma RB, Berg D, Stern M, Poewe W, Olanow CW, et al. (2015) MDS Clinical Diagnostic Criteria for Parkinson's Disease. Mov Disord 30: 1591-1601. [Crossref]

5. Vreeling FW, Verhey FR J, Houx PJ, Jolles J (1993) Primitive reflexes in Parkinson's Disease. J Neurol Neurosurg Psychiatry 56: 1323-1326. [Crossref]

6. Galvan A, Wickmann T (2008) Pathophysiology of Parkinsonism. Clin Neurophysiol 119: 1459-1474. [Crossref]

7. Rodriguez M, Morales I, Rodriguez-Sabate C, Sanchez A, Castro R, et al. (2014) The degeneration and replacement of dopamine cells in Parkinson's Disease: The role of ageing. Front Neuroanat 8: 80. [Crossref]

8. Rodriguez M, Rodriguez-Sabate C, Moralies I, Sanchez A, Sabate M(2015) Parkinson's Disease as a result of aging. Aging Cell 14: 293-308. [Crossref]

9. Levy G (2007) The relationship of Parkinson's Disease with aging. Arch Neurol 64 1242-1246. [Crossref]

10. Buchanan AS, Wilson RS, Shulman JM, Leurgaus SE, Schneider JA, et al. (2016) Parkinsonism in older adults and its association with adverse health outcomes and neuropathology. J Gerontol A Biol Sci Med Sci 71: 549-556. [Crossref]

11. Chow-Chuen J, Beran RG (2019) An independent clinical audit of an alternative treatment paradigm for the management of Parkinson's Disease. Clin Neuro Neurological Res Int J 2: 180008.

Copyright: $\odot 2020$ Beran RG. This is an open-access article distributed under the terms of the Creative Commons Attribution License, which permits unrestricted use, distribution, and reproduction in any medium, provided the original author and source are credited. 